\title{
Coping with Stress in the Forced Repatriation of Unaccompanied Asylum-Seeking Refugee Children among Swedish Police Officers and Social Workers
}

\author{
Johanna Sundqvist ${ }^{1,2}$, Mehdi Ghazinour ${ }^{2,3}$, Mojgan Padyab ${ }^{3}$ \\ ${ }^{1}$ Department of Public Health and Clinical Medicine, Epidemiology and Global Health Unit, Umeå University, Umeå, Sweden \\ ${ }^{2}$ Basic Training Programme for Police Officers, Umeå University, Umeå, Sweden \\ ${ }^{3}$ Department of Social Work, Umeå University, Umeå, Sweden \\ Email: johanna.sundqvist@umu.se
}

How to cite this paper: Sundqvist, J., Ghazinour, M., \& Padyab, M. (2017). Coping with Stress in the Forced Repatriation of Unaccompanied Asylum-Seeking Refugee Children among Swedish Police Officers and Social Workers. Psychology, 8, $97-118$.

http://dx.doi.org/10.4236/psych.2017.81007

Received: December 19, 2016

Accepted: January 10, 2017

Published: January 13, 2017

Copyright (c) 2017 by authors and Scientific Research Publishing Inc.

This work is licensed under the Creative Commons Attribution International License (CC BY 4.0).

http://creativecommons.org/licenses/by/4.0/

\begin{abstract}
Police officers and social workers are key actors in the forced repatriation of unaccompanied asylum-seeking refugee children. Police officers are tasked with arranging the children's departure, whereas social workers are responsible for the children's well-being during their stay in Sweden. To gain a better understanding of how to handle stressors and cope effectively with forced repatriation work, the current study aimed to describe and compare police officers' and social workers' coping strategies for forced repatriation work, controlling for sociodemographic characteristics and social support. Nationally distributed surveys to social workers $(n=380)$ and police officers $(n=714)$ with and without experience of forced repatriation were used, analyzed by univariate and multivariable regression models. The police officers used more planful problem-solving and self-controlling strategies, whereas the social workers used more escape-avoidance, distancing and positive reappraisal coping. Additionally, social workers with experience in forced repatriation used more planful problem-solving than those without experience. Police officers involved in forced repatriation manage their work stress via adaptive coping strategies and control over the situation, whereas social workers use more maladaptive coping strategies. Concrete tools are needed at the individual level to strengthen key actors' ability to support the well-being of unaccompanied asylum-seeking refugee children.
\end{abstract}

\section{Keywords}

Coping, Police Officers, Social Workers, Sweden, Unaccompanied Asylum-Seeking Refugee Children 


\section{Introduction}

In Swedish, police officers and social workers have legal responsibilities in the forced repatriation of unaccompanied asylum-seeking refugee children (SFS 2001:453; SFS 2005:716). Sweden receives more unaccompanied asylum-seeking refugee children than any other country in Europe (Celikaksoy \& Wadensjö, 2016), and the number of asylum applications for children increased from 7000 in 2014 to over 35,000 in 2015 (Swedish Migration Board, 2016). These children, who are under the age of 18 , come to Sweden to seek asylum without care or support from their families; however, some receive a negative asylum decision: approximately $34 \%$ of asylum applications are rejected (Swedish Migration Board, 2015). The Aliens Act (SFS 2005:716) states that children under the age of 18 are obligated to leave the country following a negative asylum decision but that children must be considered particularly vulnerable and should receive a dignified repatriation. Children may be repatriated to their home country, a transit country, or another country where the child will be received. If a child refuses to leave voluntarily and there is a risk the child may abscond, the Swedish Migration Board submits the enforcement case to the police, and the case becomes a forced repatriation. In addition to police officers, social workers are also key actors in forced repatriations. Social workers are by law (SFS 2001:453) responsible for the well-being of unaccompanied asylum-seeking refugee children during their entire stay in Sweden, whereas police officers are tasked with arranging the child's departure. These professionals work with refugee children who often are afraid of what will happen when they return to their country of origin and who express their fear through powerful emotions. Nevertheless, police officers and social workers must carry out the government's decision, although forcing such children to leave a safe and wealthy country may evoke negative emotional and mental stress.

In this article, we attempt to highlight the complexity of the work involved in the repatriation of refugee children. We do so by focusing on how police officers' and social workers' coping strategies and social support in forced repatriation work are related based on governmental and organizational demands. We first provide an overview of our previous research on forced repatriation, since this study is part of a more comprehensive research project. This is followed by a description of the coping with stress theory and its relevance to police and social work. We continue by providing a brief description of unaccompanied asylum-seeking refugee children's experience with the forced repatriation system, as police officers' and social workers' practical efforts are part of the forced repatriation process. It is worth emphasizing that based on our research findings, we view forced repatriation as a system of actors who interact with and affect each other. We then offer a more specific description of our aim, followed by a summary of the methods and empirical results, both descriptive and analytical. Lastly, we discuss the implications of the study for forced repatriation with a special focus on the actors involved, including unaccompanied asylum-seeking refugee children. 
The complex phenomena of the forced repatriation of unaccompanied asylum-seeking refugee children has been described in our previous case study, which also focused on collaboration between the actors involved in the repatriation of unaccompanied asylum-seeking refugee children (Sundqvist, Ögren, Padyab, \& Ghazinour, 2015). That study found a low level of collaboration among the actors, leading to a disorganized repatriation system characterized by professionals who either act in isolation and on the basis of their own personal preference or tend to become passive observers rather than active partners in the repatriation system. These behaviors make it difficult for those involved to fully provide dignified repatriation for refugee children. In another study, we aimed to understand the relation between police officers' and social workers' job demands and decision latitude in relation to mental health in forced repatriation work (Sundqvist, Hansson, Ghazinour, Ögren, \& Padyab, 2015). The results indicated that psychological job demand was a significant predictor of poor mental health among both social workers and police officers involved in forced repatriation work. Moreover, social workers involved in forced repatriation work had poorer mental health than police officers involved in the same work. This difference may be related to social workers' and police officers' perceptions of their roles in the forced repatriation system, as social workers perceive their supportive role as incompatible with the forced repatriation system, whereas police officers perceive their executive role as equivalent to any other police work-related task. Other studies in this project have addressed police officers' and social workers' high level access to social support and a small buffering effect in relation to mental health among police officers involved in forced repatriation work (Hansson, Hurtig, Lauritz, \& Padyab, 2016; Sundqvist, Padyab, Hurtig, \& Ghazinour, 2016).

Thus far, our research has concluded that a lack of collaboration and a disorganized repatriation system at the governmental and organizational levels leads to demanding working conditions that affect repatriation workers' mental health at the individual level, regardless of their high level of access to social support factors. Research has demonstrated that demanding work is correlated with psychological disturbances among both police officers and social workers (Backteman-Erlanson, Padyab, \& Brulin, 2013; Chopko, 2010; Dwyer, 2007; Evans et al., 2005; Johnson et al., 2005; Peterson et al., 2008). Johnson et al. (2005) found that 6 of 26 selected occupations had high scores for poor mental health and low job satisfaction, and police officers and social workers represented two of these six occupations. Furthermore, Backteman-Erlandson et al. (2013) study of the prevalence of burnout and its association with the psychosocial work environment among Swedish police found that high work demand was a risk factor for emotional exhaustion. The relationship between work-related stress and mental health outcomes are described by Karasek and Theorell's demand-control model (1990), in which psychological demands include factors such as the volume and intensity of an individual's workload and how the individual copes with unforeseen tasks, while job control refers to the individual's 
control over his or her own tasks. Therefore, to manage work and maintain wellbeing during demanding work, Folkman and Lazarus (1988a) suggest that adopting functional coping behaviors is crucial to reducing stressors.

\subsection{Theoretical Framework}

This study is based on the theory of psychological stress and coping, which has been developed over time by Lazarus and colleagues (Coyne \& Lazarus, 1980; Folkman, 1984; Folkman, Lazarus, Dunkel-Schetter, DeLongis, \& Gruen, 1986; Lazarus, 1966; Lazarus, 1981; Lazarus \& Folkman, 1984a; Lazarus \& Folkman, 1984b). According to this model, stress is defined as a relationship between an individual and the environment and is the result of the perception that the individual's environmental demands (for example, work demands) exceed his or her ability to cope with them. Furthermore, the feelings, thoughts and actions that follow a stressful encounter depend on the individual's appraisal of the situation. Stress and coping are process-oriented, focusing on what an individual actually thinks, feels, and does in a specific stressful situation and how this changes over time. Furthermore, this model emphasizes context, highlighting that specific individual and situational variables combine to create a coping outcome. This model is distinct from trait-oriented research on coping, which focuses instead on stable personality dispositions to determine what individuals typically do (Lundqvist \& Ahlström, 2006).

Two processes are essential in the model: cognitive appraisal and coping (Folkman et al., 1986). Cognitive appraisal is the process whereby one evaluates whether a specific stressful encounter is relevant to oneself, and if so, in what ways. Cognitive appraisal is divided into primary and secondary appraisal. Primary appraisal consists of the process of perceiving a threat to oneself, whereas secondary appraisal consists of the process of identifying a potential response to the threat. During the coping process, an individual appraises the actual demands of the encounter and his or her resources for managing those demands (Lazarus \& Folkman, 1984a). Coping is defined as the person's strategies for managing internal and external demands in perceived stressful situations (Folkman, 1984). The definition does not imply general assumptions about adaptive or maladaptive coping. The outcome of the specific situation determines whether the individual's coping efforts were successful. Depending upon the situational demands and available coping resources, a person's coping strategies may vary over time (Ahlström \& Wenneberg, 2002).

Coping has two widely recognized functions: dealing with the problem causing the distress (problem-focused) and regulating stressful emotions (emotionfocused) (Folkman, 1984). Problem-focused coping aims to address the source of stress and deal directly with the situation. This is an adaptive coping strategy in changeable situations, but if the situation cannot be resolved, a problem-focused coping strategy could lead to psychological stress (Lazarus, 1993). Studies of both police officers (Evans, Coman, Stanley, \& Burrows, 1993) and social workers (Ben-Zur, \& Michael, 2007; Gellis, 2002) have reported higher use of problem-focused coping strategies for stressful work events. Emotion-focused cop- 
ing, however, involves efforts to prevent or tolerate the emotions associated with a stressful situation without attempting to change the situation itself. The results of a review indicated that emotion-focused coping was negatively correlated with health outcomes (Penley, Tomaka, \& Wiebe, 2002). However, emotion-focused coping could represent a functional coping strategy in unchangeable situations (Lazarus, 1993). Both types of coping, problem-focused and emotion-focused, are part of the coping process in stressful situations. Which type is used depends on how the situation is appraised, the individual's resources and the surrounding environment.

According to Folkman and Lazarus (1991; 1984a), social support from others may function simultaneously as both a problem-focused and an emotion-focused coping strategy. Henderson, Duncan-Jones, Byrne and Scott (1980) define social support as close emotional support, appreciation and contacts within and outside the family and how people manage everyday stress through their social networks and contacts. Talking to a colleague can function as a problem-focused coping strategy when the individual receives concrete information that aids in resolving a situation. Conversely, talking to a colleague and using the emotional support obtained to regulate emotional responses arising from a stressful event functions as emotion-focused coping.

A review of gender differences in coping suggests that most gender differences are small but that women tend to exhibit more variation in coping strategies than men in stressful situations (Tamres, Janicki, \& Helgeson, 2002). Nevertheless, men engage in more problem-focused and avoidant coping behaviors, whereas women are more likely to use strategies that involve verbal expressions to others or themselves, to seek emotional support, to ruminate about problems, and to use positive self-talk.

Previous research on coping in police work (Aaron, 2000; Larsson, Kempe, \& Starrin, 1988; Morash, Haarr, \& Kwak, 2006; Patterson, 2003; Stinchcomb, 2004) has reported that police personnel use avoidant coping and problem-focused coping strategies and that distress increases when the buffering effect between problem-focused coping and work events is not supported. Stinchcomb (2004) addresses the impact of organizational stress in police work and considers coping a symptom rather than a cause of an individual's poor mental health. In their narrative study of human service workers, Astvik and Melin (2013) found that compensatory and quality-reducing strategies were risk factors for poor mental health among social workers. Furthermore, social workers used more problem-focused coping strategies in stressful work situations (Ben-Zur \& Michael, 2007; Gellis, 2002; Padyab, Ghazinour, \& Richter, 2013).

However, to our knowledge, research on police officers' and social workers' coping strategies in forced repatriation work is limited.

\subsection{Unaccompanied Asylum-Seeking Refugee Children in the Repatriation System}

The practical work of police officers and social workers in forced repatriation 
involves coping with unaccompanied asylum-seeking refugee children who will return involuntarily to their home country or another country and who have had difficult experiences in their past. Ehntholt and Yule (2006) noted that unaccompanied asylum-seeking refugee children are often exposed not only to multiple traumatic events and severe losses but also to an ongoing stressful situation in the host country while they are under asylum-seeking status. Brunnberg, Borg and Fridström (2011) argued that minimal information during the asylum process, delays, stressful interviews and uncertainty over the future could contribute to this host-country traumatization. Wright (2014) noted that unaccompanied asylum-seeking refugee children often find the thought of repatriating extremely distressing when they receive the final rejection on their asylum applications. It is not uncommon for these children to fear being detained or even killed if they return to their home countries. This finding should be added to the substantial previous research demonstrating that unaccompanied asylum-seeking refugee children often manifest symptoms of post-traumatic stress disorder (PTSD) and other mental health problems, such as depression, anxiety and sadness, even though other research has also found evidence of their resilient abilities (Chase, 2010; Ehntholt \& Yule, 2006; Lustig et al., 2004).

Chase (2010) described the complexity of being a social worker in the repatriation system and argued that encouraging a child to repatriate defies social work values and ethics. This notion was confirmed by Ghazinour et al. (2014), who reported that social workers in the repatriation system perceive that participating in the forced repatriation of a child is particularly demanding, since they believe that forced repatriation cannot be dignified and that the child would be best served by remaining in the host country. However, social workers must participate in forced repatriations and support children during this process.

Furthermore, Ghazinour et al. (2014) noted that police officers' strategies in forced repatriation work involves arguing that the children's best interest is to be removed and returned to their families in their home countries. Dorling (2008) observed that professionals justify this stance by asserting that there is no risk of persecution for children returning to their home country. This approach is consistent with police officers' executive role in this assignment, which requires them to be task oriented and follow government regulations.

The current study focuses on coping strategies among social workers and police officers in the context of the forced repatriation of unaccompanied asylum-seeking refugee children. Strategies are needed to support these professionals in managing stressors and coping effectively with their responsibilities in forced repatriation work.

\subsection{Aim}

Specifically, this study aims to describe and compare police officers' and social workers' coping strategies for forced repatriation work, controlling for sociodemographic characteristics and social support. The analysis was conducted separately among those with and without experience in forced repatriation work. 


\section{Methods}

\subsection{Setting}

Prior to 2014, the Swedish Police Authority was organized into 21 county authorities. In 2015, this structure was modified and became a single National Police Authority. County authorities generally consist of an investigation and legal unit, a crime prevention unit, a service unit, and a border police unit. In the forced repatriation system, the border police unit is primarily responsible for collaborating with the Swedish Migration Board. The police have the authority to use force to execute a repatriation. Nevertheless, compulsory methods must always be proportionate and should be employed with respect for children's dignity, basic human rights and physical integrity (Directive; SFS 1984:387; SFS 2005:716). Police may travel by themselves or with a representative of the Swedish Prison and Probation Services when accompanying unaccompanied asylum-seeking refugee children to their home country or a transit country.

Each of the 290 municipalities in Sweden has its own social services, which are regulated by the Social Services Act (SFS 2001:453). This legislation stipulates that individuals in need-including unaccompanied asylum-seeking refugee children-have the right to receive support as long as they are present in the municipality area. Municipality social services can be organized in different ways, but all the municipalities have statutory social workers responsible for unaccompanied asylum-seeking refugee children. Every child has his or her own social worker, who follows up with the child and maintains close contact with the Care Home and the child's legal guardians. Social workers use the same methods to investigate unaccompanied asylum-seeking refugee children's needs that they use for native Swedish children in the social welfare system: the Swedish version of the LACS-the Looking after Children System (Ghazinour et al., 2015; Nygren, Hyvönen, \& Khoo, 2009). This method is used in child social welfare as a care philosophy and working tool to ensure the psycho-social development of children in the care of child welfare agencies and to implement a child perspective in social welfare investigations. However, this tool was developed for children living in Sweden now and in the future. In the repatriation system, social workers are responsible for children's needs and support until the children leave the country.

\subsection{Design, Sample and Data Collection}

A cross-sectional design was used with a total of 1,094 participants: 714 police officers and 380 social workers. The study was conducted in the spring and autumn of 2014 and was based on two national self-administered surveys: one of police officers and one of social workers.

All 21 police authorities that existed in Sweden in 2014 were contacted to obtain permission to collect data from police officers, resulting in 18 participating authorities. Paper surveys were sent to all 18 human resource personnel units or squad leaders, who distributed them to individual police officers. A total of 714 police officers responded. The secrecy rules in the Swedish police organization required the use of this convenience sampling technique. A single item in the 
sociodemographic questionnaire divided the police officers into two groups: those with and those without experience working with the forced repatriation of unaccompanied asylum-seeking refugee children.

The inclusion criteria for social workers was all 265 of the 290 municipalities in Sweden that had an agreement with the Swedish Migration Board regarding the reception of unaccompanied asylum-seeking refugee children at the time of the study. Due to organizational factors at the municipality level, contact information from all 265 municipalities was obtained via e-mail. Initially, county administration boards were contacted for access to social workers' e-mail addresses at the municipality level. Additional contact information for the social workers was collected by directly contacting the municipality via phone or e-mail. Thereafter, all the social workers were contacted and asked to complete a Web-based survey. The e-mail included an information letter about the purpose of the study and a link to the Web-based survey. The letter also informed the social workers about the voluntariness of the study. In total, 506 social workers with experience working with unaccompanied asylum-seeking refugee children received the Web-based questionnaire. After two reminder e-mails, 133 replied (26\%). The other group of social workers consisted of 754 individuals who were responsible for similar tasks with other vulnerable children and/or families at the municipality level. Of these, 247 responded to the survey (33\%).

This study was part of a comprehensive research project, and ethical approval was given by the Regional Ethical Review Board at Umeå University, Sweden, Dn 2014/69-31Ö.

\subsection{Instruments}

The participants' sociodemographic characteristics were collected using a selfadministered questionnaire.

The sociodemographic characteristics consisted of variables such as age, gender, work experience, education level, and marital status. Education level and marital status were combined to categorize the participants into two groups: upper secondary education/higher education and married or cohabiting/single (including separated, divorced and widow/-er).

Social support was measured using an abbreviated version of the Interview Schedule for Social Interaction (ISSI) (Henderson et al., 1980), which has previously been tested for validity and reliability in Sweden (Undén \& Orth-Gomér, 1989). The ISSI measures aspects of social support using a quantitative (availability of social integration, AVSI) scale consisting of 6 questions and a qualitative (adequacy of social integration, ADSI) scale consisting of 8 questions. Furthermore, emotional support (attachment) was included, both in a quantitative (availability of attachment, AVAT) section with 6 questions and in a qualitative (adequacy of attachment, ADAT) section with 10 questions. The results for the four dimensions are presented as means with no cut points and standard deviations.

The revised version of the Ways of Coping Questionnaire (WOCQ) developed 
by Folkman and Lazarus (1988b) was used to assess coping. It is a widely used questionnaire that measures the cognitions and behaviors that people employ to handle the internal and external demands of perceived stressful situations, and the WOCQ has been used separately with police officers (Backteman-Erlanson et al., 2013; Patterson, 2003) and social workers (Padyab et al., 2013). The WOCQ is scenario-based and consists of 66 items. The police officers and social workers were asked to indicate the coping strategies they would use in a specific scenario. The scenario was similar for both the police officers and the social workers and contained the following information for police officers: "Two days ago, you were involved in executing a repatriation order for a 16-year-old unaccompanied asylum-seeking refugee child who told you about fleeing to Sweden and the fear of being forced to go back and then killed". The scenario for social workers included the following: "You have been a social worker for a 16-yearold unaccompanied asylum-seeking refugee child for a while. Two days ago, the child described the experience of fleeing and the fear of returning and being killed. Today, the Swedish Migration Board has rejected the child s asylum application in all instances, and the child s repatriation is a fact'. The coping strategies were then rated on a 4 -point Likert scale $(0=$ does not apply and/or not used; 1 = used to some extent; 2 = used quite a bit; and $3=$ used a great deal). The WOCQ manual by Folkman and Lazarus (1988b) suggests an eight-factor solution for the subscales, consisting of a total of 50 items: Escape Avoidance (EA), 8 items, Distancing (D), 6 items, Planful Problem Solving (PPS), 6 items, Self-Controlling (SC), 7 items, Seeking Social Support (SS), 6 items, Accepting Responsibility (AR), 4 items, Positive Reappraisal (PR), 7 items, and Confrontive Coping (CC), 6 items.

EA refers to wishful thinking and behavioral efforts used to escape or avoid a stressful situation. D consists of cognitively separating oneself and minimizing the significance of a stressful situation, while PPS involves using both deliberate problem-focused strategies to change the situation and an analytic approach to solving the problematic situation. SC consists of regulating one's feelings and actions and SS refers to informational, tangible and emotional support. AR acknowledges one's own role in the problem while $\mathrm{PR}$ involves attempting to create positive meaning from the stressor. CC describe aggressive efforts to alter the situation and suggests some degree of hostility and risk-taking (Folkman \& Lazarus, 1988b).

According to Folkman and Lazarus's (1980, 1988b) classification of these coping strategies, problem-focused coping is represented by PPS in the WOCQ, while emotion-focused coping is represented by SC, PR, D, EA.

\subsection{Statistical Analysis}

Descriptive statistics for the continuous variables are presented as means and standard deviations and as percentages for the categorical demographic variables. T-tests were used to compare the coping scores of the police officers and social workers. Univariate and multivariable regression were applied to test for the predictive value of the sociodemographic variables, working with unaccom- 
panied asylum-seeking refugee children, and social support as independent variables and the coping subscales as dependent variables.

The factor structure of the WOCQ was assessed in three steps using both confirmatory factor analysis (CFA) and exploratory factor analysis (EFA). In the first step, CFA was used to test whether the original eight-factor structure based on the WOCQ manual (Folkman \& Lazarus, 1988b) fit our data. A close fit to the model is indicated by values less than 0.05 , according to the root mean square error of approximation (RMSEA) fit index (Browne \& Cudeck, 1993). The goodness-of-fit index (GFI) and the adjusted goodness-of-fit index (AGFI) were also used. Values exceeding 0.90 indicate a good fit of the model to the data. Further, the comparative fit index (CFI) and the incremental fit index (IFI) were measured, and values equal to or higher than 0.9 for these indices indicate an acceptable fit to the model.

In the second step, we considered whether a more appropriate model could be identified for both police officers and social workers using EFA on the police data since the size of the police sample was dominant. The EFA was performed with oblique rotation due to the supposition that the factors were not independent of each other. To obtain the optimal number of factors in the EFA, parallel analysis as an accurate factor retention method was used (Hayton, Allen, \& Scarpello, 2004). In the third step, based on the EFA factor-structure on the police data, we conducted a CFA for the social workers.

The statistical analyses were performed using STATA 13.1 (StataCorp, College Station, TX), and the confirmatory factor analyses were performed using LISREL 8.8. The significance level was established at $p<0.05$.

\section{Results}

Of the 1,094 participants, 714 were police officers, of whom 157 had experience working with the forced repatriation of unaccompanied asylum-seeking refugee children. The social workers consisted of 380 individuals (133 working with unaccompanied asylum-seeking refugee children and 247 working with other children and/or families in a municipality). The characteristics of the study sample are presented in Table 1. In total, the gender distribution was 51\% male and $49 \%$ female. Both police work and social work have gender traditions, with male dominance in police work and female dominance in social work. In the police population, the male distribution was $69 \%$ ( $31 \%$ female), whereas $16 \%$ of the social workers were male ( $84 \%$ female). The proportion of those who had worked with unaccompanied asylum-seeking refugee children was $24 \%$ among the male police officers (27\% for the male social workers) and $18 \%$ among the female police officers (36\% for the female social workers). The mean age was 45 years for the police officers and 42 years for the social workers. Most of the police officers, $83 \%$, were married ( $76 \%$ among the social workers). On average, both the police officers and the social workers had over 15 years of work experience.

\subsection{Psychometric Properties of the WOCQ}

To determine the optimal factor structure for the police officers' and social 
Table 1. Characteristics of the study participants, by gender $(\mathrm{N}=1094)$.

\begin{tabular}{|c|c|c|c|c|c|c|c|}
\hline & \multicolumn{2}{|c|}{ Police Officers } & \multicolumn{3}{|c|}{ Social Workers } & \multirow{2}{*}{ Total } & \multirow{2}{*}{$P$-value c } \\
\hline & Males & Females & Total & Males & Females & & \\
\hline $\mathrm{N}$ & 494 & 220 & 714 & 59 & 321 & 380 & \\
\hline Age Mean \pm SD a years & $43 \pm 11^{\star *}$ & $39 \pm 11$ & $42 \pm 11$ & $49 \pm 12^{\star *}$ & $45 \pm 11$ & $45 \pm 11$ & $<0.001$ \\
\hline Range in Years & $24-67$ & $24-65$ & $24-67$ & $27-69$ & $22-66$ & $22-69$ & \\
\hline Marital Status \% Married & $87^{* *}$ & 74 & 83 & 85 & 74 & 76 & 0.007 \\
\hline Children \% Yes & $81^{\star *}$ & 65 & 76 & 73 & 80 & 78 & NS \\
\hline Experience with UARC b \% Yes & 24 & 18 & 22 & 27 & 36 & 35 & $<0.001$ \\
\hline \multicolumn{8}{|l|}{ Coping } \\
\hline EA & $0.5 \pm 0.4^{*}$ & $0.6 \pm 0.5$ & $0.5 \pm 0.4$ & $2.0 \pm 0.4$ & $2.0 \pm 0.2$ & $2.0 \pm 0.4$ & $<0.001$ \\
\hline PPS & $1.1 \pm 0.7^{\star * *}$ & $1.4 \pm 0.7$ & $1.2 \pm 0.7$ & $1.1 \pm 0.7$ & $1.1 \pm 0.7$ & $1.1 \pm 0.7$ & 0.005 \\
\hline SC & $1.6 \pm 0.6^{* * *}$ & $1.7 \pm 0.5$ & $1.6 \pm 0.6$ & $1.1 \pm 0.5^{\star * *}$ & $0.9 \pm 0.5$ & $1.0 \pm 0.5$ & $<0.001$ \\
\hline $\mathrm{D}$ & $1.2 \pm 0.5^{\star * *}$ & $1.0 \pm 0.5$ & $1.1 \pm 0.5$ & $2.0 \pm 0.5$ & $2.0 \pm 0.5$ & $2.0 \pm 0.5$ & $<0.001$ \\
\hline $\mathrm{PR}$ & $1.4 \pm 0.6$ & $1.4 \pm 0.5$ & $1.4 \pm 0.5$ & $1.5 \pm 0.6$ & $1.5 \pm 0.5$ & $1.5 \pm 0.5$ & $<0.001$ \\
\hline \multicolumn{8}{|l|}{ Social support variables } \\
\hline AVAT & $4.9 \pm 1.3^{* * *}$ & $5.3 \pm 1.1$ & $5.0 \pm 1.28$ & $5.2 \pm 1.2$ & $5.3 \pm 1.2$ & $5.3 \pm 1.2$ & 0.001 \\
\hline AVSI & $3.8 \pm 1.5^{* * *}$ & $4.2 \pm 1.5$ & $3.9 \pm 1.5$ & $3.6 \pm 1.4$ & $3.9 \pm 1.4$ & $3.9 \pm 1.5$ & 0.84 \\
\hline ADAT & $6.6 \pm 2.4$ & $6.8 \pm 2.2$ & $6.6 \pm 2.3$ & $5.8 \pm 2.5$ & $6.0 \pm 2.7$ & $6.0 \pm 2.6$ & $<0.001$ \\
\hline ADSI & $5.7 \pm 1.9^{*}$ & $6.0 \pm 1.8$ & $5.8 \pm 1.8$ & $5.3 \pm 1.9$ & $5.0 \pm 2.3$ & $5.1 \pm 2.2$ & $<0.001$ \\
\hline
\end{tabular}

Note. ${ }^{*} p<0.05,{ }^{* *} p<0.01,{ }^{* * *} p<0.001$ compared to females. a: $\mathrm{SD}=$ Standard Deviation; b: UARC = Unaccompanied asylum-seeking refugee children; c: $p$-value for the comparison between police officers and social workers

workers' coping strategies, two separate analyses was performed. First, a CFA was conducted to test the original eight-factor structure based on the WOCQ manual (Folkman \& Lazarus, 1988b). The model found RMSEA $=0.0729$ (90\% CI: $0.0710-0.0748)$ for the police officers and RMSEA $=0.0413(90 \% \mathrm{CI}$ : $0.0380-0.0446)$ for the social workers. To determine whether a more appropriate model could be identified for both groups, the second step involved an EFA on the police data since the size of the police sample was dominant. A parallel analysis suggested a five-factor solution consisting of the following: EA with 17 items such as "I generally avoided being with people" and "I had fantasies or wishes about how things might turn out"; $\mathrm{D}$ with 11 items such as " $I$ went on as if nothing had happened" and "I made light of the situation; I refused to get too serious about it'; and PPS with 7 items such as "I came up with a couple of different solutions to the problem" and "I changed something so things would turn out all right". Lastly, SC was represented by 14 items, including "I tried to keep my feelings about the problems from interfering with other things" and "I went over in my mind what I would say or do", and PR was represented with 6 items, such as I changed or grew as a person' and "I came out of the experience better than when I went in".

Based on the EFA factor-structure for the police data, we conducted a new 
CFA for the social workers. The modification indices suggested the removal of five items for the social workers-12, 14, 56, 59 and 66-due to low loading factors. For improved model fit, the decision was made to move items 58 and 65 from SC into PR. The overall goodness of fit for the social workers after the modifications found RMSEA $=0.0357$ (90\% confidence interval: 0.0321 $0.0392)$, GFI $=0.88, \mathrm{AGFI}=0.86, \mathrm{CFI}=0.93$, and IFI $=0.93$. In summary, the five-factor model consisted of 55 items for police officers and 50 items for social workers.

\subsection{Comparison of Coping Scores between Police Officers and Social Workers}

In total, the police officers used PPS more than the social workers $(1.2 \pm 0.7$ vs. $1.1 \pm 0.7, p=0.005$, Table 1 ), and female police officers used PPS more frequently as a coping strategy than male police officers $(1.4 \pm 0.7$ vs. $1.1 \pm 0.7, p$ $=<0.001$, Table 1). The male and female social workers used PPS to the same extent. The use of SC strategies was also higher among the police officers than the social workers $(1.6 \pm 0.6$ vs. $1.0 \pm 0.5, p=<0.001$, Table 1$)$. However, there were gender differences within the professional categories: female police officers used SC more often than male police officers, and male social workers used SC more often than female social workers.

The social workers used EA more than the police officers ( $2.0 \pm 0.4$ vs. $0.5 \pm$ $0.4, p=<0.001$, Table 1 ). There was no gender difference among the social workers, but among the police officers, females used EA strategies more than males ( $p=0.05$, Table 1$)$. Furthermore, the social workers used D coping strategies more than the police officers $(2.0 \pm 0.5$ vs. $1.1 \pm 0.5, p=<0.001$, Table 1$)$. The gender distribution was equal among the social workers, but male police officers used D strategies more often than their female counterparts $(p=<0.001$, Table 1). Positive reappraisal (PR) was used more frequently by the social workers than the police officers ( $1.5 \pm 0.5$ vs. $1.4 \pm 0.5, p=<0.001$, Table 1$)$.

\subsection{Univariate and Multivariable Regression Results for Police Officers and Social Workers, Stratified by Experience with Repatriation Work}

A bivariate model was used to examine the relationship between each independent variable and coping, in which the coping subscales were the dependent variables and sociodemographic characteristics, professional group and social support were the independent variables. PPS was significant for occupation in the univariate model, suggesting that police officers use PPS more than social workers ( $p=0.007$, Table 2 ). The results of the multivariable regression indicate that working as a police officer and being younger are predictors for higher use of PPS coping strategies (Table 2). Among the participants who had experience with forced repatriation, social workers were found to use PPS more than police officers (Beta $=0.28, p<0.001$, Table 2 ) in the univariate model. Gender was also significantly correlated with PPS in the bivariate model, suggesting that males use PPS strategies less than females (Beta $=-0.29, p<0.001$, Table 2). 
Table 2. Linear regression: Factors associated with coping subscales, by working experience with UARC

\begin{tabular}{|c|c|c|c|}
\hline \multirow{2}{*}{ Coping } & \multicolumn{3}{|c|}{ Variables with significant standardized Beta $(\mathrm{B}, \mathrm{t}, \mathrm{p})$} \\
\hline & Total $(\mathrm{n}=1094)$ & UARC $-(n=804)$ & $\mathrm{UARC}+(\mathrm{n}=290)$ \\
\hline \multicolumn{4}{|l|}{ Escape Avoidance } \\
\hline Univariate & $\begin{array}{c}\text { Social work }(1.44,56,<0.001) \\
\text { Single }(0.14,2.25,0.025) \\
\text { Male }(-0.78,-18,<0.001) \\
\text { Age }(0.01,3.4,0.01) \\
\text { AVAT }(0.07,3.8,<0.001) \\
\text { ADAT }(-0.03,-3.6,<0.001) \\
\text { ADSI }(-0.06,-4.5,<0.001\end{array}$ & $\begin{array}{c}\text { Social work }(1.39,44,<0.001) \\
\text { Male }(-0.66,-13,<0.001) \\
\text { Age }(0.02,7.2,<0.001) \\
\text { AVAT }(0.05,2.53,0.01) \\
\text { ADAT }(-0.02,-2.6,0.01) \\
\text { ADSI }(-0.06,-3.6,<0.001)\end{array}$ & $\begin{array}{l}\text { Social work }(1.6,39,<0.001) \\
\text { Male }(-1.1,-13.1,<0.001) \\
\text { Age }(-0.01,-3.6,<0.001) \\
\text { AVAT }(0.13,3.2,0.002) \\
\text { ADAT }(-0.05,-2.5,0.01) \\
\text { ADSI }(-0.07,-2.8,0.004)\end{array}$ \\
\hline Multivariable & $\begin{array}{l}\text { Social work }(1.40 .45,<0.001) \\
\text { Male }(-0.07,-2.5,0.01) \\
\text { AVAT }(0.03,2.4,0.01\end{array}$ & Social work $(1.35,34.15,<0.001)$ & $\begin{array}{l}\text { Social work }(1.5,28.7,<0.001) \\
\quad \operatorname{AVAT}(0.05,2.2,0.02)\end{array}$ \\
\hline \multicolumn{4}{|c|}{ Planful Problem Solving } \\
\hline Univariate & $\begin{array}{l}\text { Social work }(-0.12,-2.7,0.007) \\
\text { Age }(-0.005,-2.9,0.004\end{array}$ & $\begin{array}{l}\text { Social work }(-0.29,-5.96,<0.001) \\
\text { Age }(-0.004,-2.23,0.02)\end{array}$ & $\begin{array}{l}\text { Social work }(0.28,3.54,<0.001) \\
\text { Male }(-0.29,-3.6,<0.001)\end{array}$ \\
\hline Multivariable & $\begin{array}{c}\text { Social work }(-0.1,-2.3,<0.02) \\
\text { Age }(-0.05,-2.5,0.01\end{array}$ & Social work $(-0.28,-5.46,<0.001)$ & \\
\hline \multicolumn{4}{|l|}{ Self-Controlling } \\
\hline Univariate & $\begin{array}{c}\text { Social work }(-0.65,-19,<0.001) \\
\text { Male }(0.26,7.3,<0.001) \\
\text { Age }(-0.01,-5.4,<0.001)\end{array}$ & $\begin{array}{c}\text { Social work }(-0.72,-18.09,<0.001) \\
\text { Male }(0.26,6.15,<0.001) \\
\text { Age }(-0.01,-6.7,<0.001)\end{array}$ & $\begin{array}{c}\text { Social work }(-0.43,-6.8,<0.001) \\
\text { Male }(0.22,3.3,0.001)\end{array}$ \\
\hline Multivariable & $\begin{array}{l}\text { Social work }(-0.66,-16,<0.001) \\
\text { Age }(-0.004,-3.2,0.001)\end{array}$ & $\begin{array}{l}\text { Social work }(-0.71,-14.8,<0.001) \\
\text { Age }(-0.004 ;-2.2 ; 0.02)\end{array}$ & Social work $(-0.49,-6.0 .<0.001)$ \\
\hline \multicolumn{4}{|l|}{ Distancing } \\
\hline Univariate & $\begin{array}{l}\text { Social work }(0.88,29,<0.001) \\
\text { Male }(-0.37,-9.8,<0.001) \\
\text { Age }(0.004,2.4,0.017) \\
\text { AVSI }(-0.03,-2.3,0.02) \\
\text { ADAT }(-0.02,-3.4,<0.001) \\
\text { ADSI }(-0.05,-5.4,<0.001)\end{array}$ & $\begin{array}{c}\text { Social work }(0.91,24.9,<0.001) \\
\text { Male }(-0.3,-7.1,<0.001) \\
\text { Age }(0.01,5.13,<0.001) \\
\text { AVSI }(-0.03,-2.3,0.02) \\
\text { ADAT }(-0.02,-2.6,0.01) \\
\text { ADSI }(-0.04,-4.1,<0.001)\end{array}$ & $\begin{array}{c}\text { Social work }(0.87,15.6,<0.001) \\
\text { Male }(-0.5,-7.4,<0.001) \\
\text { Age }(-0.01,-3.7,<0.001) \\
\text { ADAT }(-0.03,-2.1,0.03) \\
\text { ADSI }(-0.07,-3.8,<0.001)\end{array}$ \\
\hline Multivariable & $\begin{array}{l}\text { Social work }(0.93,25,<0.001) \\
\text { Male }(0.1,2.7,0.01)\end{array}$ & $\begin{array}{c}\text { Social work }(0.98,21.53,<0.001) \\
\text { Male }(0.1,2.7,0.01) \\
\text { AVSI }(-0.02,-2.2,0.02)\end{array}$ & Social work $(0.88,11.9,<0.001)$ \\
\hline \multicolumn{4}{|c|}{ Positive Reappraisal } \\
\hline Univariate & $\begin{array}{l}\text { Social work }(0.13,4,<0.001) \\
\text { Male }(-0.07,-2.4,0.01)\end{array}$ & Social work $(0.12,3.07,0.002)$ & Social work $(0.15,2.37,0.01)$ \\
\hline Multivariable & Social work $(0.12,3.19,0.001)$ & Social work $(0.12,3.07,0.002)$ & Social work $(0.15,2.37,0.01)$ \\
\hline
\end{tabular}

However, these differences disappeared in the multivariate model. This finding is to a great extent an artifact of the high correlation between occupation and gender, as the social workers were predominantly women, while the police officers were predominately men. As the bivariate results demonstrate, the social workers used PPS more and males used PPS less to nearly the same degree (so- 
cial workers, Beta $=+0.28$; male, Beta $=-0.29)$. To differentiate the effect of gender and occupation on PPS, an additional analysis was performed in which the total direct and indirect effect of occupation was calculated. The ratio of indirect to direct effect was found to be 0.68 , suggesting that approximately $70 \%$ of the effect of occupation on PPS is indirect via gender.

In both the total population and among those without experience in forced repatriation work, being a police officer, male gender and younger age were significant predictors of SC use in the univariate model. After controlling for all the variables, police officer and age remained significant predictors for both groups, suggesting that police officers and younger people use SC more frequently as a coping strategy. Among those with experience in forced repatriation work, occupation as a police officer and male gender were significant. However, in the multivariable model, only occupation as a police officer remained significant ( $p$ $=0.001$, Table 2 ), perhaps because most of the police officers in the study were male.

In relation to EA, occupation (social worker), gender (female), age (older) and the social support variables (higher AVAT and lower ADAT and ADSI) were associated with higher use of EA in the univariate model for the overall sample and among those with and without experience in forced repatriation work (Table 2). However, in the multivariable model, only occupation (social work, $p$ $=0.001$, Table 2$)$ and AVAT $(p=0.002$, Table 2$)$, representing the availability of close emotional support, remained significant among those with experience in forced repatriation work, suggesting that social workers and those with higher levels of AVAT use EA coping strategies more frequently than others.

In the univariate model, D, occupation (social work), gender (female), age (older), and the social support variables (lower AVSI, ADAT and ADSI) were associated with more frequent use of $\mathrm{D}$ for the total population and for those without experience with forced repatriation. In the multivariable model, social work and male gender remained significant for the total study population. Among those without experience with forced repatriation, lower AVSI was associated with higher use of $\mathrm{D}$ as a coping strategy. Furthermore, in the population with experience in forced repatriation, occupation as a social worker, female gender, younger age, and lower ADAT and ADSI were related to more frequent use of $\mathrm{D}$ in the univariate model. After controlling for all the variables, only social work as an occupation remained significant in the multivariable model ( $p=$ 0.001 , Table 2).

In the univariate model, occupation as a social worker and female gender were significant predictors of PR in the total population, whereas only social work was associated with higher use of PR among those with and without experience in forced repatriation work. After controlling for all the variables in the multivariable model, occupation as a social worker was associated with higher use of PR for the total population (Beta $=0.12, p<0.001$ ) and among those without experience (Beta $=0.12, p<0.001)$ and with experience (Beta $=0.15, p=0.01)$ in forced repatriation work (Table 2). 


\section{Discussion}

The aim of this study was to compare coping strategies among police officers and social workers in a scenario involving the forced repatriation of unaccompanied asylum-seeking refugee children, taking into account sociodemographic characteristics and social support. A stratified analysis was conducted of those with and without experience in the forced repatriation of unaccompanied asylum-seeking refugee children.

The main findings indicate that police officers use PPS and SC coping strategies significantly more than social workers. Previous studies have also found that police officers use more problem-focused coping in response to stressful work events (Evans et al., 1993; Larsson et al., 1988). Further, Larsson, Kempe and Starrin (1988) noted that police officers may use SC as a strategy to cope with their work environment. Working in a provocative and unpredictable setting requires individuals to regulate their emotions to remain in control of the situation. As Wright (2014) noted, professionals working with unaccompanied asylum-seeking refugee children, who are often extremely distressed about the prospect of repatriation, may encounter such unpredictable situations. Sundqvist et al. (2015) found no difference in police officers' mental health status between those involved with forced repatriation and those involved with other police tasks. This may be related to police officers' perception of forced repatriation work equivalent to any other police task. Based on this perception, police officers use relevant tools and their training in this type of assignment to address children with dignity and remain as professional as possible. Since police officers are responsible for enforcing repatriation judgments and must make decisions regarding when and how children are repatriated, they are actively involved in the process and are generally in control of their task. According to Karasek and Theorell (1990), this is because police officers have more control over and higher decision latitude in repatriation work. This finding was supported in Sundqvist et al. (2015), who found that police officers report higher feelings of control and decision latitude than social workers. Since police officers have addressed their own needs using adaptive coping strategies and control over the situation, they can serve as a safe person for a frightened child and maintain complete focus on the child's needs.

In the overall sample, the social workers, used EA, D and PR coping more than the police officers. This is somewhat inconsistent with previous research, which has reported higher use of problem-focused coping among social workers (Ben-Zur \& Michael, 2007; Gellis, 2002; Padyab et al., 2013). A literature review by Collins (2008) found evidence that some social workers use PR coping strategies, such as "It could happen to anyone", whereas others employ defensive disengagement and use D coping strategies in stressful work scenarios, resulting in clients who are helpless, immature and difficult. Additionally, Padyab et al. (2013) described the use of PR coping among social workers in relation to client violence and reported that the item on the WOCQ with the highest mean was "I came out of the experience better than when I went in". 
The use of more EA and D coping strategies may be related to organizational factors in forced repatriation work. Unlike police officers, social workers use methods and tools that were not designed for forced repatriation. One example is the social workers' use of the LACS, an investigation tool developed for children living in Sweden now and in the future. When asked, $60 \%$ of the social workers involved in forced repatriation reported that the LACS is not appropriate for their work (Ghazinour et al., 2015). The function of emotional coping strategies at the individual level is to manage psychological stress without altering the situation. These strategies have been found to have negative associations with mental health (Penley et al., 2002); however, Lazarus (1993) argues that they have adaptive value in unchangeable situations. In situations in which the LACS is appropriate for use, social workers have the ability to perform their work autonomously to fulfill a child's needs, even if the tool is not optimized for their task. Therefore, using emotional coping strategy cannot be considered a functional coping strategy for addressing social workers' responsibilities in forced repatriation work.

At the individual level, one possible explanation for the higher use of EA and D coping among social workers could be that in forced repatriation, social workers' point of departure is governed by United Nation's Convention on the Rights of the Child in which social workers endeavor to adopt a supportive position. However, they are also emotionally affected due to the distressing situation and may consequently use EA coping more frequently. Since coping is process oriented, different coping strategies can be used simultaneously (Lazarus \& Folkman, 1984b). Using EA might activate D, and we assume that D has two aspects. On the one hand, social workers must provide a sense of safety and security to children in forced repatriation situations. On the other hand, social workers must maintain distance to be able to tolerate these children's emotional responses to forced repatriation. Using distancing and avoidant coping strategies may be beneficial for their work while enabling them to remain emotionally available to the child in need. Sustaining emotional contact with a child to fulfill their supportive assignment may only be possible for some social workers if they use a D or EA coping strategies to manage their complex and difficult work. Otherwise, social workers may need to rely on a problem-focused coping strategy that is not well-suited to the child's needs or a less avoidant coping strategy that could have even greater negative effects on the social workers. Additionally, our results reveal that the use of EA coping strategies was associated with social workers who also had high access to close emotional social support. Our previous study (Hansson et al., 2016; Sundqvist et al., 2016) demonstrated that social workers involved in forced repatriation have high access to social support that buffers the effect of poor mental health to some extent. Since forced repatriation is such a stressful and complex work assignment, social workers use social support to regulate their emotions and manage their responses to the stressful event. The current study found no difference between having or not having experience in forced repatriation work among police officers and social workers in 
terms of the coping strategies used, with the exception of PPS. In the overall sample in this study, the police officers used PPS more than the social workers. However, among those with experience in the forced repatriation of unaccompanied asylum-seeking refugee children, the difference disappeared, as these experienced social workers used PPS more frequently than their less experienced counterparts. The distribution of gender may be one explanation for this finding, as women used PPS more than men, and the social worker group was predominantly women. This finding is inconsistent with that of Tamres et al., (2002), who reported that men are over represented in the use of PPS. Another explanation for this finding might be that social workers without experience with forced repatriation responded to the scenario differently than those who had actually been involved in forced repatriation work. The results indicate that social workers without experience with forced repatriation used PPS strategies less than those who had experience. Supporting a child who fears "returning and being killed" (citation from the scenario) could be considered a stressful and unchangeable situation for professionals. Influencing an already determined government decision is impossible for social workers, even though social workers generally do not sympathize with repatriating asylum-seeking refugee children to their home country or another country (Ghazinour et al., 2014). In such situations, using a problem-focused coping strategy to attempt to address obstacles in the external environment that trigger psychological stress, forced repatriation in this case, is an ineffective coping strategy. Lazarus (1993) argued that maladaptive coping strategies could by extension lead to psychological disturbances. Social workers with experience in forced repatriation used PPS more than those without experience. Social workers who had not been involved with forced repatriation preferred to use emotion-focused coping strategies when envisioning a forced repatriation situation, whereas those who had had experience with forced repatriation used problem-focused coping and endeavored to "solve" an unsolvable situation. This might be another reason that social workers involved in forced repatriation work exhibit higher levels of psychological disturbance (Sundqvist et al., 2015). The actual stressful situation may be the reason that social workers involved in forced repatriation used maladaptive coping strategies more frequently than social workers without experience in forced repatriation. Police officers, however, have a more task-oriented assignment in forced repatriation. Unlike social workers, police officers sometimes accompany a child to the recipient country (Ghazinour et al., 2014). Social workers have reported that when the police assume responsibility for a child's return, those children occasionally leave Sweden without the social worker's knowledge or the opportunity to say goodbye (Ghazinour et al., 2014). Thus, the repatriation system is more suited to police work than social work. This could be one explanation for why police officers employ more adaptive coping strategies in this situation and are less mentally affected than social workers.

There are imitations that should be addressed in this study. Since the design was cross-sectional, no causality from the results could be inferred. However, the 
lack of existing studies drove the choice of a cross-sectional study as a starting point for identifying police officers' and social workers' coping strategies in the forced repatriation of unaccompanied asylum-seeking refugee children. Another limitation was the convenience sampling method used to recruit police officers and the low response rate among social workers. As this study used a self-report questionnaire, possible biases and inaccuracies stemming from misunderstanding and misinterpretation among the respondents could have affected the results.

\section{Implications and Recommendations}

As demonstrated in this study, both police officers and social workers involved in forced repatriation attempt to cope with this-in humanitarian terms-unnatural situation, which requires them to force a frightened child away from a state of hope for a better future toward a state of uncertainty and insecurity. All those involved, not forgetting the children themselves, are in one way or another heavily pressured by this stressful event. The Swedish government has chosen to return unaccompanied refugee children while declaring that this process should be conducted with dignity. However, policymakers have not clarified how a dignified repatriation should be performed. Therefore, to help the many actors involved in forced repatriation to implement the law in a legal and secure manner and to reduce the gap between the forced repatriation system and dignity for children's human rights, policymakers must provide national guidance in this area.

As long as low collaboration between actors and disorganized patterns in the repatriation process persist, police officers and social workers involved in forced repatriation will be required to rely on their own professionalism to continue their work creating the most dignified repatriation possible for children. However, developing concrete tools at the individual level would also be beneficial to offer all those involved the opportunity to maintain well-being in this demanding work context. One of the tools currently missing in Sweden is a specific handbook for the professionals involved in forced repatriation. This handbook could include a description of different actors' roles in forced repatriation, guidelines regarding how to collaborate with others effectively and holistically, and a specific section that could help the actors strengthen their professions against overwhelming feelings and the use of inadequate coping strategies in forced repatriation work that could lead to poor mental health.

\section{References}

Aaron, J. D. K. (2000). Stress and Coping in Police Officers. Police Quarterly, 3, 438-450. https://doi.org/10.1177/109861110000300405

Ahlström, G., \& Wenneberg, S. (2002). Coping with Illness-Related Problems in Persons with Progressive Muscular Diseases: The Swedish Version of the Ways of Coping Questionnaire. Scandinavian Journal of Caring Sciences, 16, 368-375. https://doi.org/10.1046/j.1471-6712.2002.00099.x

Astvik, W., \& Melin, M. (2013). Coping with the Imbalance between Job Demands and 
Resources: A Study of Different Coping Patterns and Implications for Health and Quality in Human Service Work. Journal of Social Work, 13, 337-360. https://doi.org/10.1177/1468017311434682

Backteman-Erlanson, S., Padyab, M., \& Brulin, C. (2013). Prevalence of Burnout and Associations with Psychosocial Work Environment, Physical Strain, and Stress of Conscience among Swedish Female and Male Police Personnel. Police Practice and Research, 14, 491-505. https://doi.org/10.1080/15614263.2012.736719

Ben-Zur, H., \& Michael, K. (2007). Burnout, Social Support, and Coping at Work among Social Workers, Psychologists, and Nurses: The Role of Challenge/Control Appraisals. Social Work in Health Care, 45, 63-82. https://doi.org/10.1300/J010v45n04_04

Browne, M. W., \& Cudeck, R. (1993). Alternative Ways of Assessing Model Fit. In K. A. Bollen, \& J. S. Long (Eds.), Testing Structural Equation Models (pp. 136-162). Newbury Park, CA: Sage.

Brunnberg, E., Borg, R., \& Fridström, C. (2011). Ensamkommande Barn: En Forskningsöversikt [Unaccompanied Children: A Research Review]. Malmö: Studentlitteratur.

Celikaksoy, A., \& Wadensjö, E. (2016). Hur harde Ensamkommande Barnen detiSverige? [How Is It for Unaccompanied Children in Sweden?]. Socialmedicinsk Tidskrift, 93, 28-36.

Chase, E. (2010). Agency and Silence: Young People Seeking Asylum Alone in the UK. British Journal of Social Work, 40, 2050-2068. https://doi.org/10.1093/bjsw/bcp103

Chopko, B. A. (2010). Posttraumatic Distress and Growth: An Empirical Study of Police Officers. American Journal of Psychotherapy, 64, 55-72.

Collins, S. (2008). Statutory Social Workers: Stress, Job Satisfaction, Coping, Social Support and Individual Differences. British Journal of Social Work, 38, 1173-1193. https://doi.org/10.1093/bjsw/bcm047

Coyne, J. C., \& Lazarus, R. S. (1980). Cognitive Style, Stress Perception, and Coping. In I. L. Kutash, \& L. B. Schlesinger (Eds.), Handbook on Stress and Anxiety: Contemporary Knowledge, Theory, and Treatment (pp. 144-158). San Francisco, CA: Jossey-Bass.

Directive 2008/11/EC of the European Parliament and of the Council of 16 December 2008 on Common Standards and Procedures in Member States for Returning Illegally Staying Third-Country Nationals (2008). Strasbourg: European Union.

Dorling, K. (2008). Seeking Change: Reforms to the Protection of Unaccompanied Asylum Seeking Children. ChildRight, 245, 14-17.

Dwyer, S. (2007). The Emotional Impact of Social Work Practice. Journal of Social Work Practice, 21, 49-60. https://doi.org/10.1080/02650530601173607

Ehntholt, K. A., \& Yule, W. (2006). Practitioner Review: Assessment and Treatment of Refugee Children and Adolescents Who Have Experienced War-Related Trauma. Journal of Child Psychology and Psychiatry, 47, 1197-1210. https://doi.org/10.1111/j.1469-7610.2006.01638.x

Evans, B. J., Coman, G. J., Stanley, R. O., \& Burrows, G. D. (1993). Police Officers' Coping Strategies: An Australian Police Survey. Stress Medicine, 9, 237-246. https://doi.org/10.1002/smi.2460090406

Evans, S., Huxley, P., Webber, M., Katona, C., Gately, C., Mears, A., Kendall, T. et al. (2005). The Impact of "Statutory Duties" on Mental Health Social Workers in the UK. Health and Social Care in the Community, 13, 145-154. https://doi.org/10.1111/j.1365-2524.2005.00540.x

Folkman, S. (1984). Personal Control and Stress and Coping Processes: A Theoretical Analysis. Journal of Personality and Social Psychology, 46, 839-852.

https://doi.org/10.1037/0022-3514.46.4.839 
Folkman, S., \& Lazarus, R. S. (1980). An Analysis of Coping in a Middle-Aged Community Sample. Journal of Health and Social Behavior, 21, 219-239.

https://doi.org/10.2307/2136617

Folkman, S., \& Lazarus, R. S. (1988a). Coping as a Mediator of Emotion. Journal of Personality and Social Psychology, 54, 466-475. https://doi.org/10.1037/0022-3514.54.3.466

Folkman, S., \& Lazarus, R. S. (1988b). Ways of Coping Questionnaire. Palo Alto, CA: Mind Garden.

Folkman, S., \& Lazarus, R. S. (1991). Coping and Emotion. In A. Monat, \& R. S. Lazarus (Eds.), Stress and Coping: An Anthology (pp. 207-227). New York: Columbia University Press.

Folkman, S., Lazarus, R. S., Dunkel-Schetter, C., DeLongis, A., \& Gruen, R. J. (1986). Dynamics of a Stressful Encounter: Cognitive Appraisal, Coping, and Encounter Outcomes. Journal of Personality and Social Psychology, 50, 992-1003. https://doi.org/10.1037/0022-3514.50.5.992

Gellis, Z. D. (2002). Coping with Occupational Stress in Healthcare. Administration in Social Work, 26, 37-52. https://doi.org/10.1300/J147v26n03_03

Ghazinour, M., Hansson, J., Lauritz, L. E., Mojgan, P., Sundqvist, J., Wimelius, M. E., \& Ögren, K. (2014). Avvisningar och utvisningar av ensamkommande flyktingbarn: Om effektivitet, värdighet och barnens bästa från tjänstemäns och gode mäns perspektiv [Deportations of Unaccompanied Asylum-Seeking Refugee Children: Effectiveness, Dignity and Children's Best Interests by Officials and Legal Guardians' Perspective]. Umeå: Umeå Univeristy.

Ghazinour, M., Hansson, J., Lauritz, L. E., Mojgan, P., Sundqvist, J., Wimelius, M. E., \& Ögren, K. (2015). En resa medtvång: Erfarenheter av avvisningar och utvisningar av ensamkommande asylsökande flyktingbarn [A Travel by Force: Experience of Deportations of Unaccompanied Asylum-Seeking Refugee Children]. Umeå: Umeå University.

Hansson, J., Hurtig, A.-K., Lauritz, L.-E., \& Padyab, M. (2016). Swedish Police Officers' Job Strain, Work-Related Social Support and General Mental Health. Journal of Police and Criminal Psychology, 1-10. https://doi.org/10.1007/s11896-016-9202-0

Hayton, J. C., Allen, D. G., \& Scarpello, V. (2004). Factor Retention Decisions in Exploratory Factor Analysis: A Tutorial on Parallel Analysis. Organizational Research Methods, 7, 191-205. https://doi.org/10.1177/1094428104263675

Henderson, S., Duncan-Jones, P., Byrne, D. G., \& Scott, R. (1980). Measuring Social Relationships the Interview Schedule for Social Interaction. Psychological Medicine, 10, 723-734. https://doi.org/10.1017/S003329170005501X

Johnson, S., Cooper, C., Cartwright, S., Donald, I., Taylor, P., \& Millet, C. (2005). The Experience of Work-Related Stress across Occupations. Journal of Managerial Psychology, 20, 178-187. https://doi.org/10.1108/02683940510579803

Karasek, R., \& Theorell, T. (1990).Healthy Work: Stress, Productivity, and the Reconstruction of Working Life. New York: Basic Books.

Larsson, G., Kempe, C., \& Starrin, B. (1988). Appraisal and Coping Processes in Acute Time-Limited Stressful Situations: A Study of Police Officers. European Journal of Personality, 2, 259-276. https://doi.org/10.1002/per.2410020404

Lazarus, R. S. (1966). Psychological Stress and the Coping Process. New York: McGraw-Hill.

Lazarus, R. S. (1981). The Stress and Coping Paradigm. In C. Eisdorfer, D. Cohen, A. Kleinman, \& P. Maxim (Eds.), Models for Clinical Psychopathology (pp. 177-214). 
New York: Spectrum.

Lazarus, R. S. (1993). Coping Theory and Research: Past, Present, and Future. Psychosomatic Medicine, 55, 234-247. https://doi.org/10.1097/00006842-199305000-00002

Lazarus, R. S., \& Folkman, S. (1984a). Coping and Adaptation. In W. D. Gentry (Ed.), The Handbook of Behavioral Medicine (pp. 282-325). New York: Guilford.

Lazarus, R. S., \& Folkman, S. (1984b). Stress, Appraisal, and Coping. New York: Springer.

Lundqvist, L.-O., \& Ahlström, G. (2006). Psychometric Evaluation of the Ways of Coping Questionnaire as Applied to Clinical and Nonclinical Groups. Journal of Psychosomatic Research, 60, 485-493. https://doi.org/10.1016/j.jpsychores.2005.08.019

Lustig, S. L., Kia-Keating, M., Knight, W. G., Geltman, P., Ellis, H., Kinzie, J. D., Saxe, G. N. et al. (2004). Review of Child and Adolescent Refugee Mental Health. Journal of the American Academy of Child \& Adolescent Psychiatry, 43, 24-36. https://doi.org/10.1097/00004583-200401000-00012

Morash, M., Haarr, R., \& Kwak, D. H. (2006). Multilevel Influences on Police Stress. Journal of Contemporary Criminal Justice, 22, 26-43. https://doi.org/10.1177/1043986205285055

Nygren, L., Hyvönen, U., \& Khoo, E. (2009). The Travelling Idea of Looking after Children: Conditions for Moulding a Systematic Approach in Child Welfare into Three National Contexts-Australia, Canada and Sweden. Australian Social Work, 62, 491-506. https://doi.org/10.1080/03124070903281135

Padyab, M., Ghazinour, M., \& Richter, J. (2013). Coping and Mental Health of Iranian Social Workers: The Impact of Client Violence. Social Behavior and Personality: An International Journal, 41, 805-814. https://doi.org/10.2224/sbp.2013.41.5.805

Patterson, G. T. (2003). Examining the Effects of Coping and Social Support on Work and Life Stress among Police Officers. Journal of Criminal Justice, 31, 215-226. https://doi.org/10.1016/S0047-2352(03)00003-5

Penley, J. A., Tomaka, J., \& Wiebe, J. S. (2002). The Association of Coping to Physical and Psychological Health Outcomes: A Meta-Analytic Review. Journal of Behavioral Medicine, 25, 551-603. https://doi.org/10.1023/A:1020641400589

Peterson, U., Demerouti, E., Bergström, G., Samuelsson, M., Åsberg, M., \& Nygren, Å. (2008). Burnout and Physical and Mental Health among Swedish Healthcare Workers. Journal of Advanced Nursing, 62, 84-95. https://doi.org/10.1111/j.1365-2648.2007.04580.x

SFS (1984). Police Act (p. 387). Stockholm: Department of Justice.

SFS (2001). Social Services Act (p. 453). Stockholm: Department of Justice.

SFS (2005). Aliens Act (p. 716). Stockholm: Department of Justice.

Stinchcomb, J. B. (2004). Searching for Stress in All the Wrong Places: Combating Chronic Organizational Stressors in Policing. Police Practice and Research, 5, 259-277. https://doi.org/10.1080/156142604200227594

Sundqvist, J., Hansson, J., Ghazinour, M., Ögren, K., \& Padyab, M. (2015). Unaccompanied Asylum-Seeking Refugee Children's Forced Repatriation: Social Workers' and Police Officers' Health and Job Characteristics. Global Journal of Health Science, 7, $215-$ 225. https://doi.org/10.5539/gjhs.v7n6p215

Sundqvist, J., Ögren, K., Padyab, M., \& Ghazinour, M. (2015). Collaboration Patterns among Swedish Professionals in the Repatriation of Unaccompanied Asylum-Seeking Refugee Children: An Explorative Study. European Journal of Social Work, 19, 901916. https://doi.org/10.1080/13691457.2015.1082981

Sundqvist, J., Padyab, M., Hurtig, A., \& Ghazinour, M. (2016). The Association between 
Social Support and Mental Health of Social Workers and Police Officers in Work with Unaccompanied Asylum-Seeking Refugee Children's Forced Repatriation: A Swedish Experience. Manuscript in Press.

Swedish Migration Board (2015). Avgjorda asylärenden beslutade av Migrationsverket. http://www.migrationsverket.se/download/18.7c00d8e6143101d166d1aad/14518945874 13/Avgjorda+asyl\%C3\%A4renden+2015+-+Asylum+desicions+2015.pdf

Swedish Migration Board (2016). Nyheter om ensamkommande barn och ungdomar. http://www.migrationsverket.se/download/18.2d998ffc151ac387159a280/146305912062 1/05+Aktuellt+om+maj+2016.pdf

Tamres, L. K., Janicki, D., \& Helgeson, V. S. (2002). Sex Differences in Coping Behavior: A Meta-Analytic Review and an Examination of Relative Coping. Personality and Social Psychology Review, 6, 2-30. https://doi.org/10.1207/S15327957PSPR0601_1

Undén, A.-L., \& Orth-Gomér, K. (1989). Development of a Social Support Instrument for Use in Population Surveys. Social Science \& Medicine, 29, 1387-1392. https://doi.org/10.1016/0277-9536(89)90240-2

Wright, F. (2014). Social Work Practice with Unaccompanied Asylum-Seeking Young People Facing Removal. British Journal of Social Work, 44, 1027-1044.

https://doi.org/10.1093/bjsw/bcs175

Submit or recommend next manuscript to SCIRP and we will provide best service for you:

Accepting pre-submission inquiries through Email, Facebook, LinkedIn, Twitter, etc. A wide selection of journals (inclusive of 9 subjects, more than 200 journals) Providing 24-hour high-quality service User-friendly online submission system Fair and swift peer-review system Efficient typesetting and proofreading procedure Display of the result of downloads and visits, as well as the number of cited articles Maximum dissemination of your research work

Submit your manuscript at: http://papersubmission.scirp.org/

Or contact psych@scirp.org 